\title{
Urgences
}

\section{La semaine}

\section{Danielle Bérubé}

Numéro 7, 2e trimestre 1983

URI : https://id.erudit.org/iderudit/025104ar

DOI : https://doi.org/10.7202/025104ar

Aller au sommaire du numéro

Éditeur(s)

Urgences

ISSN

0226-9554 (imprimé)

1927-3924 (numérique)

Découvrir la revue

Citer ce document

Bérubé, D. (1983). La semaine. Urgences, (7), 45-49.

https://doi.org/10.7202/025104ar

Ce document est protégé par la loi sur le droit d'auteur. L'utilisation des services d'Érudit (y compris la reproduction) est assujettie à sa politique d'utilisation que vous pouvez consulter en ligne.

https://apropos.erudit.org/fr/usagers/politique-dutilisation/ 
DANIELLE BÉRUBÉ

La semaine 


\section{LA SEMAINE}

Des traces dans la neige d'un enfant égaré au coin de ma rue et le jour s'en va

Doux pas feutrés de l'escalier "colimaçon" grimpent par deux et la porte se referme

Ombrage sur vitre glacée où la nuit s'étire enfin la main essuie la buée et le coeur s'endort 


\section{DIMANCHE}

Trop grand d'amour

comme neige sur les toits

quand prendre la vie

demande tant

Trop long I'amour

comme soleil aux yeux

quand dire les mots

permet tant

\section{LUNDI}

Du souffle court récupéré de fin de semaine

Au risque du 9 à 5

I'enjambement de tant de gens

éparpille toute logique

entre des bras...

... si chauds

\section{MARDI}

Second mouvement

en hebdomadaire machinal

Les rouages basculent

en nonchalance quotidienne

Au deuxième tour de poinçon

la machine s'embraye

Le coup est lancé! 


\section{MERCREDI}

L'ambivalence en semaine pose trop de questions

Au centre du septuple les paroles perdent quelques grenailles de sens continu

Le mi-temps s'achève... 


\section{JEUDI}

En sortie de cinéma quelques heures de foule où le bruit mange...

... tant de silences...

... d'heure tardive en levée tôt...

\section{VENDREDI}

Aux prémices du bonheur en renouveau des draps les yeux s'agrandissent comme tant d'amour... ... à donner comme tant d'affection... ... à vendre

\section{SAMEDI}

Remplie de tristesse en mélancolie de pénombre

Tout au fond dans quelqu'endroit du coeur par une nuit de grands vents une douce musique... entre des draps tout nouveaux 